\title{
Autonomia política como experiência comunicativa de bricolagem e práticas de resistência na gambiarra ${ }^{1}$ \\ Political autonomy as a communicative experience of bricolage and resistance practices in gambiarra
}

\author{
Elisa Beatriz Ramírez Hernández $z^{2}$ \\ Francine Altheman ${ }^{3}$ \\ Ângela Cristina Salgueiro Marques ${ }^{4}$ \\ Eduardo de Jesus ${ }^{5}$
}

Resumo: Este trabalho pretende refletir acerca de um modo específico de bricolagem, a gambiarra, em seus entrelaçamentos com: a) processos estético-políticos de constituição da autorrealização e autonomia dos sujeitos; b) uma poética do conhecimento que se serve da bricolagem para libertar linguagens, corpos e objetos de roteiros e scripts valorativos que engessam o olhar e impedem questionamentos e resistências. Aborda-se primeiramente a relação entre a construção da autonomia e a bricolagem através do modo como a gambiarra define modos de fazer e viver em Cuba. Em seguida, se analisa como, nas manifestações dos secundaristas em 2015, a bricolagem permitiu variar as formas dos enunciados existentes e reinventar suas coordenadas de enunciação, libertando palavras, imagens, signos de suas funcionalidades habituais.

Palavras-chave: bricolagem; gambiarra; autonomia; resistência; literaridade.

1 Este texto é parte de pesquisa apoiada pelo CNPq e pela Fapemig.

2 Universidade Federal de Minas Gerais (UFMG). Belo Horizonte, MG, Brasil. https://orcid.org/0000-0001-8704-2227 E-mail: elisabeatriz88@gmail.com

3 Universidade Federal de Minas Gerais (UFMG). Belo Horizonte, MG, Brasil. https://orcid.org/0000-0002-1768-7617 E-mail: franaltheman@gmail.com

4 Universidade Federal de Minas Gerais (UFMG). Belo Horizonte, MG, Brasil. https://orcid.org/0000-0002-2253-0374 E-mail: angelasalgueiro@gmail.com

5 Universidade Federal de Minas Gerais (UFMG). Belo Horizonte, MG, Brasil. https://orcid.org/0000-0002-7369-001X E-mail: edujesus2010@gmail.com 
Abstract: This paper aims to reflect about a specific way of bricolage, the gambiarra, and its connections with: a) aesthetic-political processes of constitution of the self-realization and autonomy of the subjects, and b) a poetics of the knowledge that uses bricolage to expand languages, bodies and objects beyond pre-fixed scripts that limit perspectives and block questioning and resistance. Firstly, we outline the relationship between the construction of autonomy and bricolage by looking at the ways in which gambiarra defines specific knowledge and lifestyles in Cuba. Then we analyze how the bricolage created in the manifestations of the Brazilian secondary schools in 2015 led to a variation of existing discourses and allowed to reinvent their enunciation, by releasing words, images and signs from their common uses.

Keywords: bricolage; gambiarra; autonomy; resistance; literarity. 


\section{Introdução}

Existem diversas formas de conhecimento; alguns são bem estruturados, cartesianos, construídos nos campos da tecnociência, cheios de certezas e de comprovações, se estruturam na experimentação exaustiva e, naturalmente, têm seu valor reconhecido. No entanto, sabemos que a esses se somam (hibridizam, derivam, contrapõem) outros conhecimentos originados na urgência do cotidiano e que se estruturam diante dos inúmeros desafios que enfrentamos no nosso dia a dia. Esse conhecimento, pouco sistematizado, ligeiramente desestruturado e muito intuitivo, é mais descontrolado e, ao mesmo tempo, criativo e ousado porque desafia esses saberes configurados, abrem brechas para a invenção, a criação, as apropriações, recriações e subversões dos materiais, objetos e símbolos em nosso entorno mais imediato. Essas soluções - invenções cheias de talento e de uma ousada e subversiva sofisticação - povoam nossos modos de realizar, produzir e fazer acontecer o cotidiano.

Essas duas formas de conhecimento foram intensamente discutidas em obras de diversos pensadores importantes do século XX, como o antropólogo Claude Lévi-Strauss, que colocou em oposição o conhecimento bem articulado, metódico e sistemático - a engenharia, por exemplo - e o conhecimento mais intuitivo, que privilegia o improviso e a colagem de diversos materiais. Assim surge na figura do bricoleur, palavra que se origina de bricolage, que se traduz para o português como bricolagem - ou conjunto de atividades (reparos domésticos, pintura, artesanato, decoração, jardinagem etc.) desenvolvidos para uso próprio, sem utilização de mão de obra especializada.

Jacques Derrida (2013), tratando da questão da linguagem em sua apropriação radical do texto de Lévi-Strauss, viu nessa forma de conhecimento construída pelo bricoleur uma importante via de singularidade na construção dos discursos e de apropriação da linguagem pelo modo como absorve, rearticula e ressignifica os sentidos.

Para além do âmbito da linguagem e se aproximando da nossa experiência cotidiana, o que esses autores apontam, de alguma forma, é esse caráter libertário do bricoleur, que, com seu conhecimento criativo, 
intuitivo e afetuoso, acumulado na experiência mais direta com o real, se insere no mundo e rearticula os poderes instituídos pelo conhecimento especializado. Subverte, apropria e faz de qualquer operação, por mais cotidiana que seja, um espaço para a invenção.

Há um potencial político no gesto da bricolagem: a escolha de materiais, o encontro de semânticas, sintaxes, texturas e formas coloca em relação elementos heterogêneos capazes de gerar estranhamento e suspensão (suspeição) da familiaridade. O bricoleur tem conhecimentos e domínio de códigos de percepção, reconhecimento e valorização das virtualidades contidas em materiais, signos e objetos diversos, utilizando-os para a elaboração inventiva e singular de novos códigos e objetos. Poderíamos definir o seu gesto criativo a partir da reflexão feita por Agamben em Meios sem fim (2000, p. 56): "há um gesto quando nos tornamos sujeitos de uma ação, quando fazemos com que ela seja nossa. É a subjetivação do gesto que faz a diferença: o ator não age, ele se autoriza do gesto - ele não é autor do gesto, mas torna-se autor pelo gesto".

A agência do bricoleur tem duas dimensões que gostaríamos de salientar neste trabalho: (i) a construção da autonomia política; (ii) a produção de formas menores de resistência (DELEUZE e GUATTARI, 2014), sustentadas pela experimentação e pela invenção de enunciados e cenas dissensuais de enunciação (RANCIÈRE, 2000a).

Retrabalhar códigos, quadros de sentido e esquemas de apreciação e valorização implica manipular os signos, indagar a linguagem, procurar a própria linguagem, configurar um enunciado e, com ele, outra forma de enunciação, assumindo responsabilidade sobre ela. Esse entendimento do gesto da bricolagem considera como central a questão da autonomia e das capacidades de autorrealização dos sujeitos em condições adversas e em meio a constrangimentos de poder e dominação. $\mathrm{Na}$ primeira parte do artigo, tratamos da relação entre a construção da autonomia e a bricolagem através do modo como a gambiarra define modos de fazer e viver em Cuba.

A segunda parte de nosso argumento confere ênfase à dinâmica de resistência ligada à bricolagem. Realizar uma ação que implica criar algo 
singular a partir da mistura de referências é destituir os objetos, palavras, corpos de uma designação consensual e naturalizante que busca atribuir a cada coisa uma utilidade, uma serventia e um valor. A bricolagem faz variar as formas dos enunciados existentes e reinventa suas coordenadas de enunciação. Nesse sentido, ela liberta os objetos, palavras, imagens, signos de suas funcionalidades habituais, permitindo-lhes a oportunidade de ser outra coisa e/ou parte integrante de outra coisa que antes não existia. Esse movimento permite que a relação classificatória "uma coisa, um nome” dê lugar ao excesso de nomes e, com isso, provoca um curto-circuito nas relações de controle e ordenação. Nessa parte do texto, trabalhamos o conceito de literaridade (literarity) presente no pensamento de Jacques Rancière, entrelaçando-o com uma breve reflexão acerca das formas enunciativas utilizadas no movimento dos secundaristas na cidade de São Paulo em 2015, que ocorreu após o governo do estado anunciar uma reorganização escolar.

A aproximação entre as experiências e potências transformadoras da gambiarra em Cuba e em São Paulo tendem a revelar como, no contexto latino-americano, a improvisação e o risco assumido em contextos de precariedade social, política e econômica constituem o "espaço que se estabelece entre a ordem e a desordem, entre a contenção e a soltura diante do peso da norma" (MONTEIRO, 2018, p. 197). A difícil transição econômica e política em Cuba e o aprofundamento do modelo neoliberal predatório no Brasil acentuam o fato de que os adjetivos "vulnerável" e "precário" servem para estigmatizar e regular (muito pela sintaxe do risco e do autogoverno/autocontrole) grupos e povos. Contudo, se ressemantizados, esses termos parecem atender a esforços mais amplos de se politizar a injúria, o sofrimento e as violências estatais que reduzem e controlam os desejos e agenciamentos transformadores. Como ressalta Monteiro (2018, p. 221-222):

A política, num momento assim, diz da capacidade de continuar produzindo em meio à adversidade, fazendo algo com aquilo que se tem de mais precário e, portanto, de mais precioso, cabendo à mão agarrar o que estiver a seu alcance. Se por um lado não convém reduzir o futuro 
a uma simples gambiarra, por outro lado o poder da precariedade é o motor de qualquer gesto que aponte para o novo.

Sob esse aspecto, o sujeito político vulnerável e precário não pode ser definido como vítima, dependente, inativo. Precariedade não é um conceito essencialmente associado a sofrimento e destituição, tampouco define unicamente uma propensão de estar suscetível ao dano. Há potencialidades e ambiguidades nessa noção que devem ser consideradas. Lazzarato (2006, p. 218), por exemplo, afirma que o sujeito precário permanece na indefinição, na zona fronteiriça entre o trabalhador e o desempregado, o artista e o bricoleur, configurando um modo de vida no qual "as relações não estão codificadas, pois elas são, de modo contraditório e simultâneo, fonte de assujeitamento político, de exploração econômica e de ocasião a ser aproveitada”. Segundo ele, o precário resta ainda um sujeito não totalmente codificado pelo neoliberalismo e, por isso mesmo, não institucionalizado e normatizado, tendo a chance de construir múltiplas lutas por suas identidades em devir. Descodificados, os precários em Cuba e no Brasil, adultos e jovens, são "esquizorrevolucionários" (PELBART, 2002), construindo a si mesmos e às suas experimentações em meio a gambiarras insurgentes.

\section{Autonomia e bricolagem}

A autonomia, princípio que defende a soberania dos indivíduos e grupos contra as imposições e violências que os ameaçam, não está relacionada ao individualismo ou à autossuficiência que apaga as particularidades das relações sociais que constituem as trajetórias dos sujeitos e cerceiam suas escolhas e preferências. Ela também, por isso mesmo, não pode ser pensada de maneira descolada de aspectos culturais e de socialização. Em vez disso, sua construção é intersubjetiva e exige que pensemos sobre: a) relações de poder; b) elementos ligados a valores, práticas e modos de subjetivação; c) competências comunicativas originadas nas redes interativas que as pessoas estabelecem umas com as outras; d) experiências (BIROLI, 2012, 2013). A dimensão da experiência nos interessa mais de perto aqui, uma vez que acreditamos que todos os sujeitos 
desenvolvem sua autonomia em condições adversas e marcadas por inúmeros constrangimentos e cerceamentos de poder. Contudo, o que vai diferenciá-los em termos de conquista da autonomia são os modos como, em suas vivências diárias, encontram/elaboram saídas para suas dificuldades e, muitas vezes, as produzem sob a forma de gambiarras.

O sujeito autônomo deve ser capaz de produzir sentido ao juntar os fragmentos de suas experiências. Deve ser capaz também de se ver como autor de sua própria história e de suas identidades, fazendo escolhas que não se restringem a optar entre alternativas socialmente disponíveis, mas evidenciando um desdobramento complexo dos padrões de socialização e das relações nas quais estão posicionados. A autonomia envolve, assim, um jogo delicado entre a identificação de constrangimentos de ação e a definição de possibilidades de ação a partir da valorização de experiências não totalmente identificadas pelos padrões de dominação (BIROLI, 2013). Mas ela também é resultado de um processo ético, no qual nossas realizações são alcançadas sempre em interdependência e, por isso mesmo, sempre em condições de vulnerabilidade (exposição ao outro). Alcançar a autonomia implica assumir a responsabilidade derivada de nossas conexões, necessidades e vínculos, o que requer olhar com mais vagar e cuidado para as situações, os encontros, os afetos e as práticas de escuta que envolvem o contato com a alteridade (BUTLER, 2016).

Dito de outro modo, a autonomia se refere tanto às condições em que as escolhas são definidas quanto à autodeterminação dos sujeitos, revelando como lidam, em sua experiência concreta, com assimetrias de poder e barreiras impostas à sua emancipação. Uma visão exigente de autonomia, ao desconsiderar as vulnerabilidades e precariedades que atravessam diferentemente as vidas dos sujeitos, pode apagar o potencial autonômico de seus variados projetos ao negligenciar que as oportunidades e a capacidade de autorrealização não são as mesmas para todos. Ainda que os sujeitos tenham acesso à mesma rede de bens e infraestrutura, são distintas as vidas, as capacidades, as gambiarras possíveis, bem como as privações e repressões sofridas (COLE, 2016), que alterarão a sua concepção de injustiça e os limites e possibilidades de resistência. 
Assim, em um primeiro plano, a questão seria “saber quais são os recursos, materiais e simbólicos, disponíveis no processo em que os indivíduos se constituem como sujeitos de suas vidas" (BIROLI, 2016, p. 44). E, num segundo plano, se indagar acerca de como os sujeitos relacionam, montam e articulam esses recursos de modo a construir alternativas plausíveis aos obstáculos e problemas que diante deles se apresentam.

Nesse sentido, projetos identitários autônomos são fruto de bricolagens que combinam singularidades e condições comuns, investimento pessoal e contribuições oriundas das relações, revelando uma fronteira entre as determinações estruturais e as diferentes formas de experiência, de posicionamentos e localizações sociais que produzem fissuras nos modos de reprodução da opressão e da precariedade.

\section{Possibilidades e constrangímentos à ação protagônica em Cuba}

O discurso midiático internacional tende a enquadrar a Revolução Cubana como imagem homogênea de um processo social que tem mudado muito ao longo de seis décadas. Os anos de 1960 e 1970 marcaram transformações estruturais que radicalizaram o projeto político no país. Já na década de 1980, se consolidava a decisão de um futuro socialista sob a proteção econômica da União Soviética (URSS). Parecia que realmente o socialismo se tornava uma opção viável para o mundo. No entanto, o desmanche do bloco comunista europeu, em 1989, trouxe um desafio gigante para os cubanos. O corte de suprimentos soviéticos para a nação caribenha, o escasso desenvolvimento da economia interna e as sanções financeiras impostas pelos Estados Unidos e outros países capitalistas fizeram com que Cuba entrasse em uma profunda crise econômica na década de 1990.

Embora esse fenômeno tenha sido amplamente estudado a partir de uma perspectiva econômica, outros autores apontam que os difíceis anos 1990 levaram ao questionamento dos fundamentos de legitimação do sistema político cubano e contribuíram para o renascimento 
da sociedade civil (BOBES, 2013). O grande desafio passou a ser não apenas se defender de ataques externos, mas conseguir sobreviver no dia a dia em prol de um projeto político nacional. Essa capacidade de resistência se traduziu em pequenas ações cotidianas que, ao longo dos anos, tornaram-se uma forma de vida marcada pela presença particular da gambiarra, a bricolagem, a inovação.

Assim, a partir de uma conjuntura política específica, o apelo constante a recursos de sobrevivência levou os cubanos a se reconhecerem no imaginário popular como seres criativos, engenhosos, invencíveis. É possível também que essas sejam características próprias da cultura cubana que, diante de um cenário de adversidades, emergiram naturalmente como mecanismo de resposta. Propomos a seguir uma breve análise sobre alguns exemplos que ilustram como a gambiarra se instituiu como tática cotidiana dos cubanos para solucionar os problemas mais básicos e como isso se relaciona com seu exercício de construção da autonomia.

A maioria dos registros que existem sobre "inventos cubanos" se referem a necessidades de primeira ordem: alimentação, transporte, energia elétrica, proteção contra as altas temperaturas do clima tropical, entre outras. A falta de combustível no país provocou constantes cortes de energia que duravam quase o dia todo. As narrativas em torno dos "apagões” cubanos ganharam centralidade na construção da memória sobre essa época, acionando simbolicamente uma capacidade extraordinária de resistência e assimilação das dificuldades econômicas. Uma blogueira cubana relata como eram construídas centrais de energia artesanais com baterias de automóveis: "os artefatos de conexão imprescindíveis para aquelas centrais eram a geladeira e o televisor. O primeiro por motivos óbvios; e o segundo porque era preciso assistir à telenovela brasileira, que era quase exclusivamente a única diversão da época" (ÁLVAREZ, 2015, tradução nossa).

Outro protagonista dessa história se conhece popularmente como chismosa (fofoqueira), nome metafórico que descreve uma lâmpada construída com um pote de vidro, querosene, fios de tecido e os antigos tubos de alumínio para pasta de dente. A chismosa, sempre vigilante 
durante longos períodos de escuridão, se tornou a fonte de luz mais comum nas noites cubanas nos anos $1990 .^{6}$

Figura l - Lâmpada improvisada conhecida como chismosa (fofoqueira).
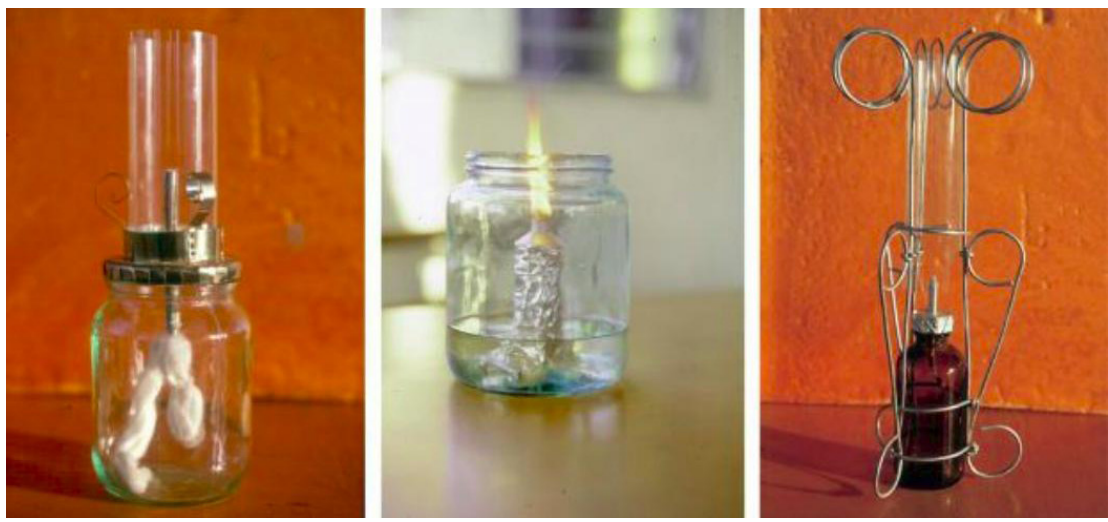

É interessante observar aqui a relevância que adquire o processo de transformação, os meios pelos quais se consegue alcançar um fim, a materialidade reformulada pela inteligência humana que subverte uma ordem comum preestabelecida, a nova relação que emerge entre as partes e o todo. Há, inclusive, um gesto de subversão implícito na concepção de que "a gambiarra, no esforço de integrar fragmentos, ainda que díspares, para que formas e funções se cumpram, realiza arremedos inovadores" (SEDLMAYER, 2017, p. 65).

A noção de interação dos indivíduos com o mundo que os rodeia marca uma dimensão política da gambiarra. Sedlmayer (2017) recupera o pensamento do filósofo italiano Giorgio Agamben para indicar a presença de uma operação que desativa o velho uso das coisas através da criação de um novo uso. Essa restituição do uso comum pode acontecer a partir de diversos procedimentos que marcam a singularidade de cada experiência, sempre permeada pelo descobrimento - nesse caso, pela atribuição de novas funcionalidades específicas aos objetos disponíveis no mundo em que os sujeitos se desenvolvem.

6 Todas as imagens utilizadas provêm da mesma fonte: Te presento 20 imágenes... (2015). 
Uma variedade de inovações se desenvolveu também em torno dos ventiladores por causa do forte calor no clima insular. A nova classe de eletrodomésticos foi criada a partir de hélices feitas de discos de vinil colocadas em ventiladores russos (Figura 2) ou motores de máquinas de lavar de origem russa adaptados a velhos ventiladores de metal (Figura 3). Esses e outros exemplos têm se incorporado no discurso de artistas contemporâneos que tematizam a história recente do país, como é o caso do projeto "Desobediência tecnológica", desenvolvido por Ernesto Oroza (2016b).

Figura 2 - Ventiladores artesanais baseados em modelo russo.
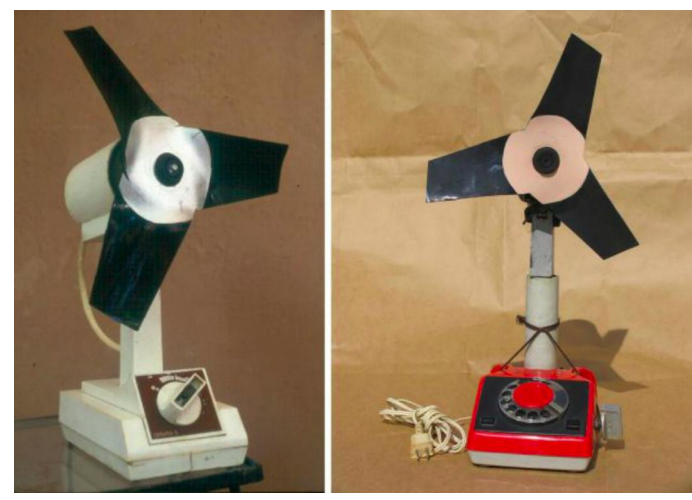

Figura 3 - Ventilador com motor de máquina de lavar russa da marca Aurika 70.

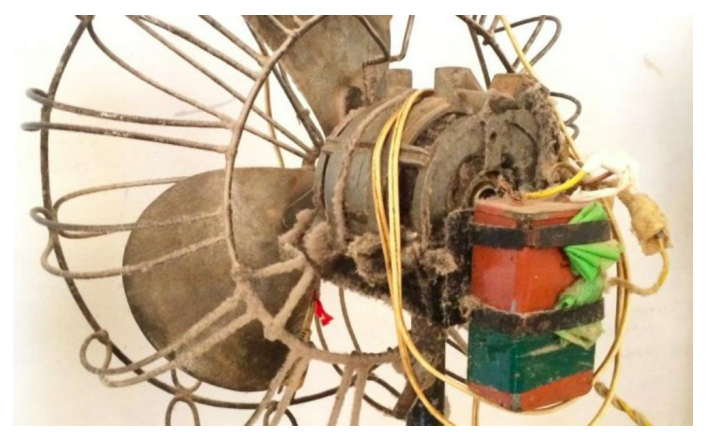

Dessa forma, a frutífera aliança de Cuba com os países soviéticos deixou uma herança de tecnologia russa na ilha que, devido à sua durabilidade, foi sendo readequada constantemente a outros fins. Os motores 
das populares máquinas de lavar da marca Aurika 70 encontraram novos usos na estrutura de equipamentos para pequenos negócios, como lixadoras de sapateiros, máquinas de copiar chaves, cortadoras de grama e todo tipo de instrumento a motor elétrico (OROZA, 2016a). Nesse sentido, uma estética própria dos países soviéticos passou a fazer parte da cotidianidade da ilha para além do rompimento de laços políticos com a URSS, como lembrança, talvez, de um tempo passado de dependência econômica que, de alguma forma, se desenhava no rosto da crise.

Na reutilização dos motores de máquina de lavar se faz presente uma intenção de generalizar as funções de uma parte do todo a partir da avaliação de possibilidades e escolha por semelhança. Nesse exercício reflexivo, o motor se desloca do aparelho como um todo e passa a ser considerado apenas por sua característica primária. Se os cubanos hoje aprenderam a viver com apenas o essencial na vida (o que talvez seja impensável para cidadãos nascidos no sistema capitalista), isso se deve, em grande medida, a um tipo de aprendizado em que se faz necessário distinguir o essencial do descartável.

A questão da reformulação de usos, a gambiarra, ocupou também um papel principal no âmbito da cozinha cubana. A bisteca feita de casca de toranja temperada se tornou quase um símbolo da época (ÁLVAREZ, 2015), assim como outras soluções ante a falta de alimentos e equipamentos para cozinhar. O provisório se torna permanente uma vez que essa inventividade se transforma, por meio de trocas comunicativas espalhadas ao longo do tempo, em aprendizado coletivo, reconfigurando o significado da gambiarra.

O gesto criativo que representa a gambiarra traz geralmente uma relação intrínseca não apenas com um estado de necessidade ou limitação de opções, mas com o sentido efêmero desse tipo de solução e seu impacto na construção de agenciamentos autônomos. A agência e o protagonismo dos sujeitos carecem de autonomia quando suas preferências e escolhas são determinadas por componentes situacionais, contextuais, políticas, culturais ou relacionais que escapam ao seu controle. É importante, nesses casos, sempre considerar os contextos e as assimetrias 
de recursos e de oportunidades que atravessam as escolhas dos sujeitos. Para definir a autonomia, não se considera apenas uma distinção entre escolhas voluntárias e coercitivas, como se entre elas não houvesse toda uma gama de questões que as entrelaça. As escolhas não são feitas de modo isolado e isento de intervenções externas, mas constituem uma trajetória interligada à definição e redefinição constante de quem somos.

Figura 4 - Panela que mantém a pressão com colheres.

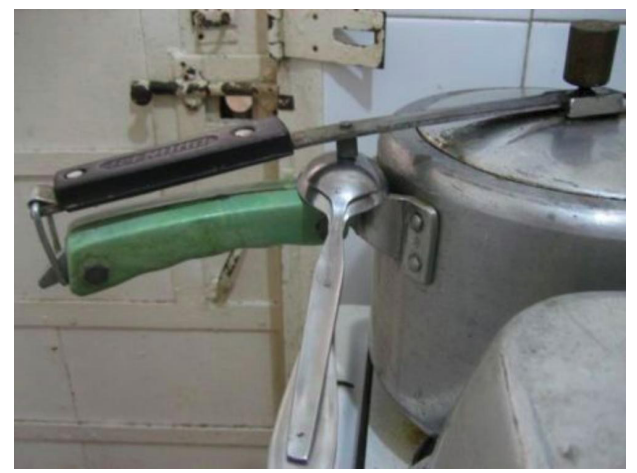

Figura 5 - O ferro de passar roupa usado como fogão para cafeteira.

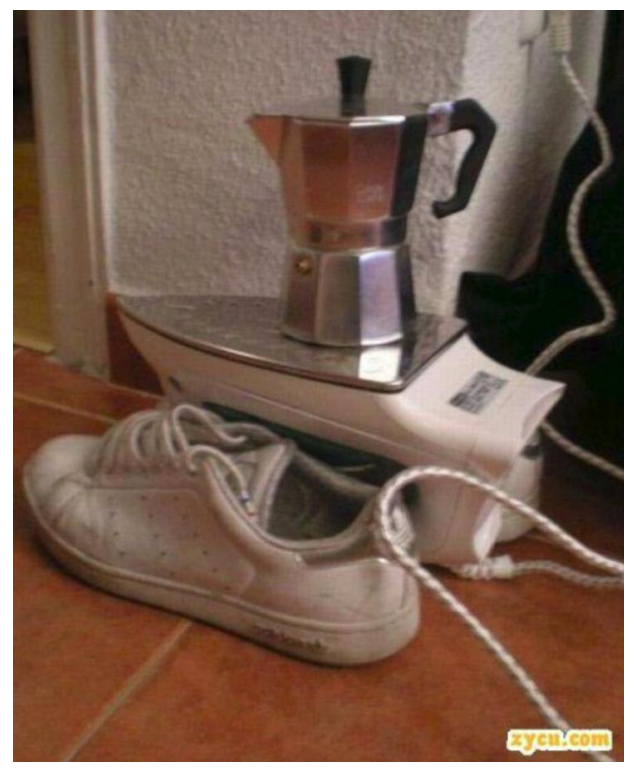


Escolhas são feitas em situações de restrição, coação e constrangimento, mas isso não significa que as pessoas deixam de agir e tomar decisões de modo próprio ou que não produzam resistências diante dos códigos dominantes (SCOTT, 1990). Contudo, nem sempre a consideração das fronteiras entre livre decisão e constrangimentos reflete a complexidade dos elementos em jogo quando se trata de falar das interfaces entre autonomia e opressão. Existem arranjos variados no processo de construção da autonomia (BIROLI, 2012) e todos eles, em alguma medida, se servem de táticas e bricolagens que retiram palavras e objetos da posição em que estão inseridos no quadro consensual sensível definido por uma rede dominante de significações, dificultando sua localização e seu posicionamento no sistema de coordenadas policiais onde habitualmente se localizam (RANCIÈRE, 2012).

Atualmente, muitos turistas que visitam Cuba ficam impressionados com a quantidade de automóveis americanos antigos (dos anos 1940 e 1950) que transitam nas ruas como resultado de adaptações em seu funcionamento mecânico. A construção de "ônibus” com partes de caminhões e as embarcações artesanais em que os cubanos empreendiam ilegalmente o trajeto migratório rumo à Flórida (EUA) são também exemplos de meios singulares de transporte desenvolvidos em condições extremas.

Figura 6 - Ônibus feito com partes de caminhão.

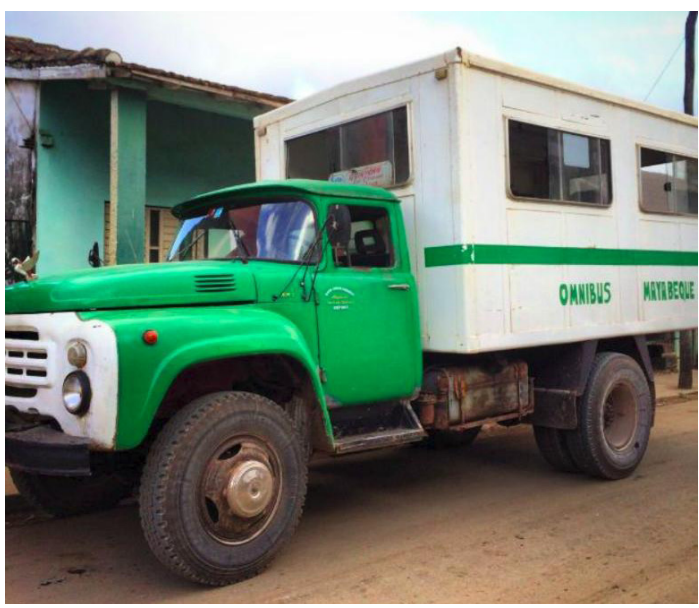


Figura 7 - Embarcação artesanal usada pelos cubanos na migração marítima para os Estados Unidos.

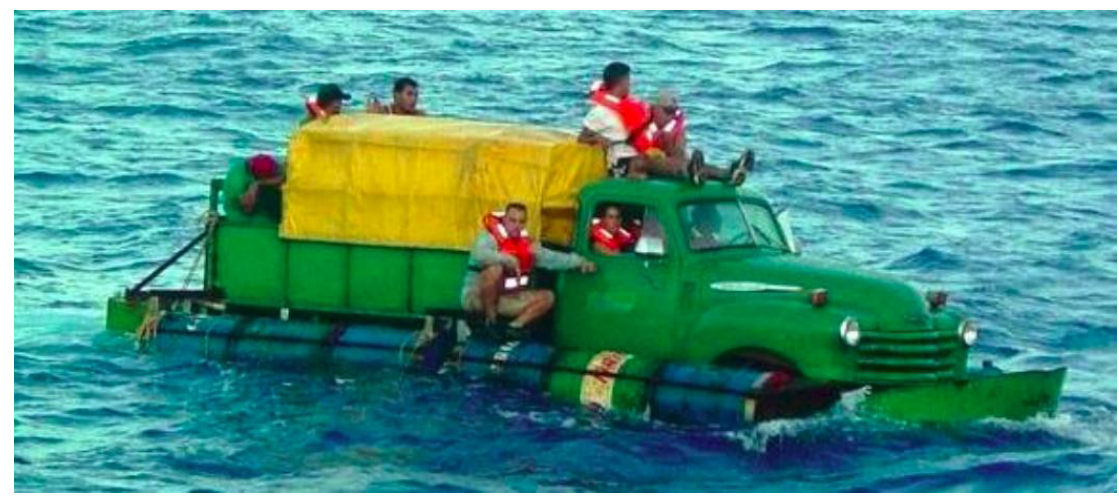

A originalidade é certamente um traço distintivo da gambiarra como expressão de vitalidade, de manifestação existencial (SEDLMAYER, 2017). Ela carrega uma multiplicidade de sentidos construídos no ato de fazer, ler e decodificar uma situação de conflito presente que pode alcançar até mesmo os limites do extraordinário, o incrível. Assim, a gambiarra atua também como elemento organizador de uma memória e de uma experiência específica, costurando momentos singulares que transitam nos limites entre a realidade e a imaginação.

No terreno da tecnologia, surgiram também soluções inovadoras como as antenas de televisão feitas com bandejas de alumínio (Figura 8) e a substituição, em vários casos, de um tipo de material ou artefato por outro similar (Figura 9). As tentativas de burlar limitações tecnológicas continuam sendo muito frequentes em Cuba. Influências culturais externas têm reconfigurado a forma de pensar da população e geram uma crescente curiosidade por aparatos tecnológicos e suas funcionalidades desviáveis.

Nesse caso, a gambiarra não se relaciona diretamente com uma vocação de reciclagem ou com o exotismo e a espetacularização que podem ser incorporados como interpretações de práticas similares. No entanto, a experiência cubana acaba por folclorizar o experimento econômico socialista e se encaixa numa interpretação de contestação ao estilo de consumo capitalista, embora isso seja apenas um resultado colateral. 
[Na gambiarra,] a lógica do consumo encontra a afirmação de um lugar à beira, apartada da quantificação, do consumismo, pois nela não se troca a torneira, não se compra um novo guarda-chuva, não se adquire uma nova bota, nem se descarta a tampa que passou a não fechar a panela (SEDLMAYER, 2017, p. 61).

Figura 8 - Antena de TV feita com bandejas de alumínio.

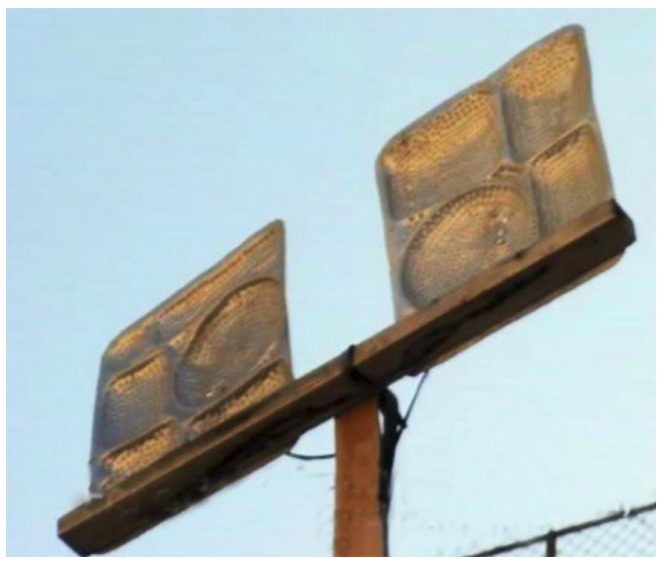

Figura 9 - Controle de TV com adaptação da bateria.

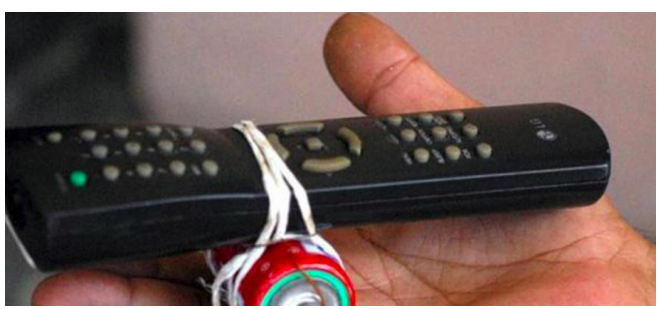

A atitude gambiarrista dos cubanos pode ser lida, claro, de várias maneiras. Ela foi uma atitude de apoio de um povo em defesa de seus ideais políticos, mas talvez, depois de um tempo, tenha se tornado um lugar de conformidade, passando por um processo de acomodação em que o fazer se transfigura em padecer. De qualquer forma, a figura da gambiarra em Cuba tem o mérito de expressar o que pode haver de espontaneidade em um povo que funciona maiormente guiado por diretrizes estatais. 
A gambiarra, nesse caso, encarna a imagem da precariedade em constante tensão com processos autonômicos de resistência.

Mas é preciso salientar aqui que a vida não é só um "recurso" a ser gerido através das lentes do Estado, das instituições, das estatísticas de mortalidade, como descreve Foucault (1980) ao cunhar o termo biopoder. A vida deve ser apreendida de dentro, na carne da experiência cotidiana dos sujeitos. Foucault, em seus escritos do final dos anos 1970 e início dos anos 1980, interroga o biopoder em busca daquilo que, na vida, resiste a ele pela criação de formas de subjetivação que escapam aos biopoderes. A relação ética consigo mesmo e com os outros é, segundo ele, a fonte da emancipação e da criação transformativa, implicadas em todas as relações de poder. Contudo, ele apenas tangencia essa discussão acerca de uma potência da vida, sem ter tido tempo suficiente para avançar os insights que integram os volumes de Ditos e escritos.

É nesse ponto que o trabalho de Hardt e Negri (2000) merece nossa atenção, pois eles se servem da reflexão de Foucault para conferir novo sentido aos conceitos de biopoder e biopolítica: contra a reprodução e governo dos modos de vida e das consciências pré-aprovadas, eles detectam a biopotência das relações de cooperação e hospitalidade, os agenciamentos criativos e os vínculos políticos e estéticos. Com uma argumentação muito afinada às proposições de Deleuze e Guattari (2014), Hardt e Negri afirmam que a vida e o ser vivente são os pontos nodais das novas lutas políticas. Nesse sentido, para além dos enquadramentos institucionais, são as narrativas e trocas comunicativas que os engendram que devem se tornar objeto de investigação de trabalhos que têm como foco desvelar os fluxos de poder que, sob o pretexto de "empoderar", "emancipar" e garantir "soberania” a sujeitos marginalizados, acabam por expor e aprofundar violências, sofrimentos morais e danos identitários.

Segundo esses autores, é imperativo nos perguntarmos de que maneiras podem surgir, no interior da máquina de produção de subjetividades, novas formas de inventar valorizações e autovalorizações de modos de viver. O que a política faz com a vida e com as vidas, para eles, não é só 
uma questão de discursos e tecnologias, estratégias e práticas. É também uma questão do modo concreto como indivíduos e grupos são tratados, sob quais princípios e em nome de que moral, implicando frequentemente desigualdades e falta de reconhecimento.

A gambiarra, enquanto biopotência, se relaciona com a experimentação permanente, com novas formas de cooperação, novos desejos, novas crenças e outras subjetividades coletivas (PELBART, 2002). Na seção seguinte, fazemos breve reflexão acerca de agenciamentos e bricolagens insurgentes que colocam em xeque o monitoramento biopolítico foucaultiano.

\section{Literaridade e bricolagem de códigos nas manifestações e insurgências urbanas}

A gambiarra, ao nos interpelar através de sua inquietante estranheza, toma forma na apropriação de características de discursos/objetos anteriormente existentes na criação de novas produções simbólicas. Uma criação que se revela, segundo Sedlmayer (2017), dupla na medida em que faz emergir algo ressemantizado, ao mesmo tempo que expõe uma identidade do sujeito bricoleur a partir das escolhas que efetua.

Sob esse prisma, a noção de bricolagem se aproxima de uma poética do conhecimento (RANCIÈRE, 2000a), ou seja, uma reorganização e (re)criação de percepções aceitas da realidade, reorganizando toda uma forma de conhecer e apreender. Em sua obra A noite dos proletários, Rancière investiga cartas e documentos escritos por operários franceses no século XIX que utilizavam para criar, ler e trabalhar a própria linguagem o tempo que teriam para dormir. Segundo ele, um operário alcança, com a leitura e a escrita, a capacidade de se conectar a uma comunidade sensível parcial, aleatória e que não se vincula necessariamente a sua classe social, mas que permite pequenas invenções no ato mesmo de fazer circular histórias, objetos e enunciados, multiplicando as racionalidades disponíveis no gesto de conferir uma forma singular à capacidade de fazer e dizer que pertence a todos. A poética do 
conhecimento consiste, então, em uma operação na linguagem e com a linguagem que retira os objetos, as narrativas e os corpos de um status que a história social ou cultural atribuiu a eles, permitindo a emergência de um excesso de nomes, palavras e usos.

O desenvolvimento da intelectualidade do operário e as atividades de leitura e escrita que realizam durante a noite revelam um curto-circuito na circulação hierarquizada dos saberes e enunciados. O gesto de escrever significa ter acesso a uma dinâmica comunicativa na qual as palavras se tornam órfãs, disponíveis para todos, sem serem guiadas pela voz de um mestre que pretensamente sabe como elas devem ser relacionadas a coisas e quem tem direito ou não de fazer uso apropriado delas. Escrever liberta as palavras de uma relação dada entre signos e corpos, disponibilizando a enunciação a qualquer um (RANCIÈRE, 2000b, 2006, 2009).

Uma das manifestações mais evidentes da poética do conhecimento, segundo Rancière, é a literaridade (literarity), descrita por ele como um modo de circulação da escrita pautado em um excesso de palavras, um princípio de desordem, uma potencialidade comum de experiência individual e coletiva, o poder do demos de alterar a distribuição de palavras (partilha política do sensível). A questão da política da literaridade em Rancière não está ligada diretamente à fala ou à escrita, mas à acessibilidade e disponibilidade da escrita (ação de escrever) a todos. O excesso de palavras desafia um sistema que condiciona a expressão e a recepção de textos e imagens.

Esse excesso de palavras, ao qual chamo de literaridade, interrompe a relação entre uma ordem do discurso e sua função social. Ou seja, a literaridade refere-se, ao mesmo tempo, a um excesso de palavras disponíveis em relação à coisa nomeada; ao excesso relacionado aos requerimentos para a produção da vida; e finalmente, ao excesso de palavras diante dos modos de comunicação que funcionam para legitimar a própria ordem adequada (RANCIÈRE, 2000a, p. 115).

Mas a literaridade não é só o excesso que configura uma potência que permite uma recombinação de signos capaz de desestabilizar as evidências dos registros discursivos dominantes: ela é o exercício mesmo 
do trabalho com a linguagem, da bricolagem com signos e enunciados, proporcionando outros arranjos e outras formas de apreender o visível e sua significação. Os falantes, em condição de igualdade (não está em jogo seu status), utilizam experimentalmente a escrita para criar "um certo espaço comum, um modo de circulação da linguagem e do pensamento que não tem nem um emissor legítimo nem um receptor específico, tampouco um modo de transmissão regulado" (RANCIÈRE, 2000b, p. 12).

Um exemplo de bricolagem que subverte os sentidos consensuais de circulação da palavra é a elaboração dos cartazes escritos à mão pelos estudantes secundaristas em protesto contra o anúncio de reorganização escolar feito pelo governo do estado de São Paulo em setembro de 2015, que ameaçava fechar 94 escolas e afetar outras $56 \mathrm{em}$ todo o estado. Ao tomarem para si o gesto de inventar e fazer circular suas próprias palavras, colocam em prática o mesmo gesto dos operários que tiveram suas cartas analisadas por Rancière: um modo de circulação da palavra escrita que pertence à partilha democrática do sensível.

Nas manifestações dos jovens secundaristas, sobretudo aquelas de 2015,7 o cartaz certamente é uma arte minoritária extremamente potente. É possível aqui estabelecer uma relação interessante entre a literaridade e o conceito de "literatura menor" cunhado por Deleuze e Guattari (2014). A literatura menor é por eles definida como uma “sintaxe incorreta" (DELEUZE e GUATTARI, 2014, p. 40), desterritorializada: uma sintaxe para gritar e também para "dar ao grito uma sintaxe". Talvez uma sintaxe que, ao mesmo tempo, conecta e desconecta as palavras de seu uso habitual, que opera mostrando o que pode ser dito e o que não pode. Uma sintaxe que revela o valor coletivo da enunciação que forja os meios de colocar em prática uma sensibilidade solidária e insurgente.

7 No dia 23 de setembro de 2015 , os principais jornais noticiavam o programa de reorganização da rede de ensino, que transferiria, já no ano letivo seguinte, mais de um milhão de alunos para que as escolas fossem divididas por ciclos. Como consequência dessa medida, mais de 150 escolas seriam afetadas, com encerramento de turnos e ciclos (MONTEIRO, 2015). 
Figura 10 - Matéria publicada no portal Jornalistas Livres (TATEMOTO, 2015).

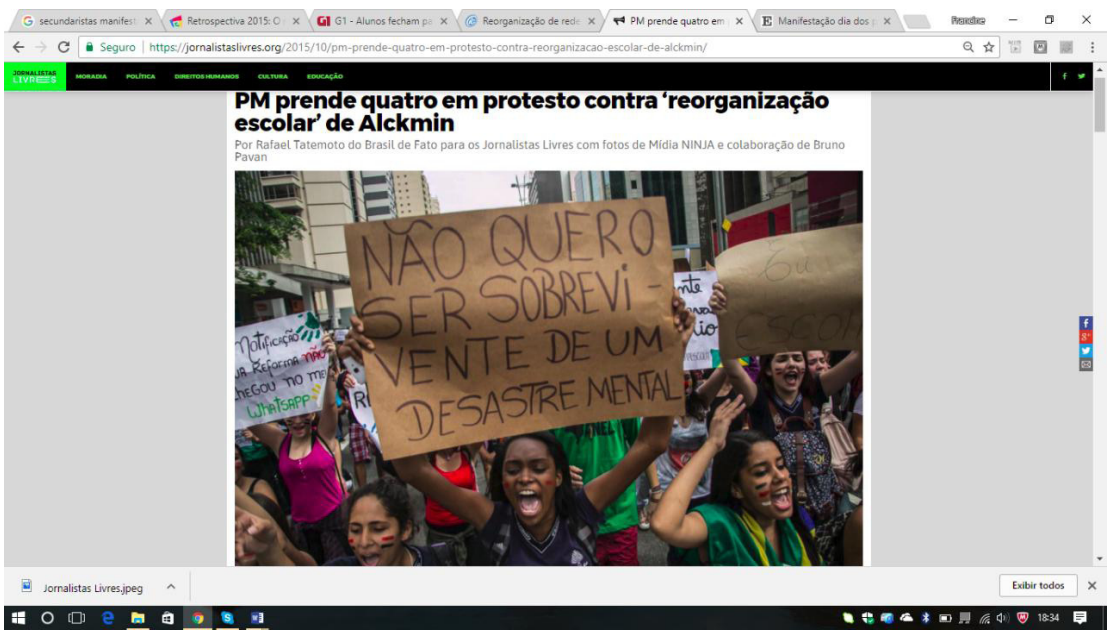

Crédito da foto: Mídia Ninja.

Feito no calor da hora, composto de materiais diversos, escrito de próprio punho, o cartaz (empunhado e carregado junto aos corpos em movimento) revela o modo como os secundaristas produziram uma escrita desgarrada das redes sociais (que, por mais liberdade que promovam, estão minadas pelos fluxos controladores do capital) e da mídia tradicional. O próprio gesto de feitura do cartaz e de carregá-lo junto a si é político, uma vez que a política da escrita consiste numa forma de experiência estética baseada na libertação da palavra de seus fluxos habituais de produção e circulação e na igualdade que se instaura quando qualquer um pode dela se assenhorar sem a necessidade de seguir um roteiro ou fórmulas específicas de enunciação. Trata-se de uma igualdade sensória e expressiva em vez de uma igualdade apenas legal ou econômica.

O registro escrito e criativo das demandas dos manifestantes em cartazes pode ser avaliado, na perspectiva de Rancière (1995), como um ato que associa o corpo insurgente à palavra proferida, libertando o enunciado dos modos legítimos do falar e do ouvir. As palavras escritas nos cartazes podem ser apropriadas por qualquer um, configurar nova 
cena de fala, colocar-se à disposição, além de caracterizar a indeterminação simultânea da referência original do enunciado e da identidade do enunciador. A escrita menor embaralha qualquer relação ordenada do fazer, do ver e do dizer.

Os cartazes e as performances dos secundaristas mostram como criatividade, linguagem e materialidade da expressão (linguagem, poiesis, produção) compõem, para Rancière (2009), a tríade central para a emancipação e autonomia dos sujeitos. Segundo ele, cada um tem de descobrir por si mesmo, em sua própria linguagem e sintaxe, as relações e acessos a um mundo comum. É através do trabalho com a linguagem (assim como a literatura), da bricolagem e gambiarra com os códigos (o corpo da letra e os corpos insurgentes), que percebemos uma poética de criação de cenas dissensuais nas quais sujeitos e objetos antes não figurados se tornam visíveis e têm suas palavras consideradas.

A fala expressa nos cartazes estabelece uma narrativa afetiva de identidade na qual o "eu" é estabelecido como protagonista a partir do qual se realizará a apropriação reflexiva da alteridade e do mundo. Daí a diferença política básica entre narrar e ser narrado por outrem: a perspectiva de narrar, a centralidade, ainda que momentânea, de quem conta a própria história desloca as linhas de força constitutivas de qualquer narrativa para o sujeito narrador, em condição tornada excêntrica em relação às narrativas dominantes dentro de uma sociedade. É por isso que, para os jovens, narrar a própria vida, contar a própria história em oposição às normatizações narrativas que os constituem como uma alteridade numa história que igualmente não é a deles - parece ser uma condição essencial da vida política que se desenha nas tramas conversacionais do cotidiano.

Os corpos e rostos majoritariamente femininos que aparecem na Figura 10, assim como os dizeres do cartaz em primeiro plano, nos revelam a emergência de um sujeito político coletivo mobilizado não por uma identidade social que declara sua precariedade, mas pelo desafio que lança “às formas de poder policial e econômico que sequestram 
incessantemente as chances que tem uma vida de se tornar vivível" (BUTLER, 2016, p. 60), sem se contentar apenas com a sobrevivência.

Por isso, a assembleia e as articulações permitem o aparecimento dos jovens como ato de palavra, um ato minoritário de soberania e autonomia que trabalha contra a óbvia e natural disposição dos corpos e das formas de enunciação. A assembleia, segundo Butler (2016), abrange uma pluralidade de corpos mobilizados em uma forma de demonstração de resistência e de igualdade diante de uma crescente desigualdade. Ela fala através de uma pluralidade de faces e corpos que configura ações e produz um povo através da "autodesignação compartilhada com os outros” (BUTLER, 2016, p. 59). Um povo e sua formação não necessitam, segundo Butler, de uma unidade, mas tem sua emergência em um conjunto de debates no qual define o que quer e quais agenciamentos vai utilizar. A formação de um povo é uma experimentação que evidencia “a potencial alegria da recomposição cotidiana do mundo [...] sempre que nos entregamos à criação, à experimentação e à invenção com o que se tem à mão, e não com aquilo que falta" (MONTEIRO, 2018, p. 198-200).

Corpos em articulação, em aliança, tomam espaços públicos ou se rebelam em consonância, ainda que isoladamente, e podem lutar contra sua fixação em categorias, contra a reificação de enquadramentos biopolíticos que os retêm em posições desprovidas de agência e soberania. Para ela, corpos reunidos em assembleia performam um ato de soberania e de resistência através de sua vulnerabilidade e, com isso, a performatividade dos corpos vulneráveis traz consigo uma forma de agir, falar, expor e demandar que requer outra configuração das relações que tornam as vidas possíveis, potentes e valorizáveis.

\section{Considerações finais}

A constituição do sujeito político emancipado implica que ele deve buscar sua autonomia através de um investimento pessoal - trabalhar a própria linguagem e se expressar com autenticidade, ética e 
compromisso (FOUCAULT, 1994, 1995) -, mas também de um encontro com os outros - um encontro que não é tranquilo, mas povoado de tensões e violências diversas. Há, nessa concepção, a ideia de que a agência dos sujeitos toma forma em contextos concretos de vida e experiência, articulada por feixes de relações, assimetrias e potencialidades que impedem a consideração dos sujeitos como agentes isolados, afastados de práticas relacionais e comunicativas que os ajudam a definir e defender interesses e preferências. Assim, a subjetivação requer articulação e combinação entre elementos diversos e que movem a agência dos sujeitos. Ela pode ser aproximada a um exercício de bricolagem constante entre o já dado e o devir, entre hegemonia e minoria, entre atual e virtual.

A capacidade de agência moral autônoma dos sujeitos se conecta com a definição de si a partir da definição do tipo de vida que se deseja viver e como os sujeitos procuram torná-la possível. Entretanto, há inúmeros limites e obstáculos para a construção relacional da autonomia, dificultando as condições concretas de sua efetivação. A autonomia envolve a criação e invenção de modos específicos de ser/existir/aparecer diante dos outros apesar das contingências e assimetrias produtoras de desigualdade e sofrimento, modos de ser e viver que se equilibram entre relações estratégicas (forma de relação mais comum em nosso cotidiano, marcada por uma mistura de acolhimento ao outro e violência contra o outro) e relações de dominação (nas quais o poder sobre o outro não deixa que as relações sejam flexíveis a mudanças). Nesse caso, a dimensão política da gambiarra se apresenta como um "apesar de": uma resistência que se desenha a partir de descobertas, tentativas, inventividade e experimentação dos indivíduos que reelaboram constantemente suas possibilidades, suas linguagens e seus devires. Apesar das assimetrias e desigualdades estruturais diversas, as táticas da gambiarra têm impacto na definição das possibilidades, ambições e escolhas efetivamente disponíveis para os indivíduos. 


\section{Referências}

AGAMBEN, G. Means without end: notes on politics. Minneapolis: Londres: University of Minnesota Press, 2000.

ÁLVAREZ, S. Los diez mejores inventos de la crisis cubana de los 90. [s. 1.], 2015. Disponível em: https://goo.gl/p4CkhV. Acesso em: ago. 2017.

BIROLI, F. Agentes imperfeitas: contribuições do feminismo para a análise da relação entre autonomia, preferências e democracia. Revista Brasileira de Ciência Política, Brasília, n. 9, p. 7-39, 2012.

- Autonomia, opressão e identidades: a ressignificação da experiência na teoria política feminista. Revista Estudos Feministas, Santa Catarina, v. 21, p. 81-105, 2013.

. Autonomia, preferências e assimetria de recursos. Revista Brasileira de Ciências Sociais, São Paulo, v. 31, n. 90, p. 39-57, 2016.

BOBES, V. C. Cuban civil Society during and beyond the special period. International Journal of Cuban Studies, Londres, v. 5, n. 2, p. 168-183, 2013.

BUTLER, J. We, the people: thoughts on Freedom of Assembly. In: BADIOU, A. et al. What is a people? Nova York: Columbia University Press, 2016. p. 54-64.

COLE, A. All of us are vulnerable, but some are more vulnerable than others: the political ambiguity of vulnerability studies, an ambivalent critique. Critical Horizons, v. 17, n. 2, p. 260-277, 2016.

DELEUZE, G.; GUATTARI, F. Kafka: por uma literatura menor. Belo Horizonte: Autêntica, 2014.

DERRIDA, J. Gramatologia. São Paulo: Perspectiva, 2013.

FOUCAULT, M. Les techniques de soi. In: DEFERT, D.; EWALD, F.; LAGRANGE, J. (Orgs.). Dits et écrits. 1954-1988. Paris: Gallimard, 1994. p. 785-814.

FOUCAULT, M. O sujeito e o poder. In: RABINOW, P.; DREYFUS, H. (Orgs.). M. Foucault: uma trajetória filosófica para além do estruturalismo e da hermenêutica. Rio de Janeiro: Forense Universitária, 1995. p. 231-249.

FOUCAULT, M. Poder de morte e direito sobre a vida. In: dade. v.l A vontade de saber. Rio de Janeiro: Graal, 1980. p. 127-152.

HARDT, M.; NEGRI, A. La production biopolitique. Multitudes, n. 1, p. 16-28, 2000. LAZZARATO, M. As revoluções do capitalismo. Rio de Janeiro: Civilização Brasileira, 2006.

MONTEIRO, A. SP vai transferir mais de 1 milhão de alunos para dividir escolas por série. Folha de S. Paulo, São Paulo, 23 set. 2015. Cotidiano. Disponível em: https://goo. gl/Fcb6ur. Acesso em: 26 abr. 2017.

MONTEIRO, P. A gambiarra como destino. Serrote, n. 28, p. 197-222, mar. 2018.

OROZA, E. Aurika 70. Emesto Oroza, 2016a. Disponível em: https:/goo.gl/DaF3jM. Acesso em: ago. 2017.

. Desobediencia tecnológica. Emesto Oroza, 2016b. Disponível em: https://goo. gl/NXqPyw. Acesso em: ago. 2017.

PEDROSA, A. Gambiarra - Cao Guimarães. In: TRIENAL POLI/GRÁFICA DE SAN JUAN: América Latina y el Caribe, 2, 2009, Porto Rico. Anais... Porto Rico, 2009. 
PELBART, P. P. Pouvoir sur la vie, puissance de la vie. Multitudes, Paris, n. 9, p. 25-35, 2002.

RANCIÈRE, J. Dissenting words: a conversation with Jacques Rancière. Diacritics, Baltimore, v. 30, n. 2, p. 113-126, 2000a.

La Mésentente - politique et philosophie. Paris: Galilée, 1995.

Le coup double de l'art politisé: entretien avec Gabriel Rockhill. Lignes, Fécamp, v. 1, n. 19, p. 141-164, 2006.

Literature, politics, aesthetics: approaches to democratic disagreement. Interviewed by Solange Guénoun and James H. Kavanagh. Substance, Madison, n. 92, p. 3-24, 2000b.

. O destino das imagens. Rio de Janeiro: Contraponto, 2012.

. O espectador emancipado. São Paulo: Martins Fontes, 2010.

The method of equality: an answer to some questions. In: ROCKHILL, G.;

WATTS, P. (Orgs.). Jacques Rancière: history, politics, aesthetics. Durham: Londres: Duke University Press, 2009. p. 273-288.

RANCIÈRE, J. The use of distinctions. In: CORCORAN, S. (Org.). Dissensus: on politics and aesthetics. Londres: Continuum, 2010. p. 205-218.

SCOTT, J. Domination and the arts of resistance - hiddens transcripts. New Haven: Yale University Press, 1990.

SEDLMAYER, S. Jacuba é gambiarra. A jacuba is a gambiarra. Belo Horizonte: Autêntica, 2017.

STRAUSS, C. O pensamento selvagem. Campinas: Papirus, 2005.

TATEMOTO, R. PM prende quatro em protesto contra 'reorganização escolar' de Alckmin. Jornalistas Livres, São Paulo, 9 out. 2015. Disponível em: https://goo.gl/HTFDuS. Acesso em: 1 out. 2017.

TE PRESENTO 20 IMÁGENES que confirman que los cubanos somos los hombres más creativos del mundo. (+Fotos). Cubanos por el mundo, 30 set. 2015. Disponível em: https://goo.gl/c3SeQn. Acesso em: 10 set. 2017.

\section{Sobre os autores}

Elisa Beatriz Ramírez Hernández - Mestranda no Programa de Pós-graduação em Comunicação Social da Universidade Federal de Minas Gerais (UFMG).

Francine Altheman - Doutoranda no Programa de Pós-graduação em Comunicação Social da UFMG. 
Ângela Cristina Salgueiro Marques - Professora do Programa de Pós-graduação em Comunicação Social da UFMG.

Eduardo de Jesus - Doutor em Comunicação Social pela Escola de Comunicações e Artes da Universidade de São Paulo (ECA-USP). Professor do Programa de Pós-graduação em Comunicação Social da UFMG.

Data de submisão: 12/02/2018

Data de aceite: 15/06/2018 